\title{
Serine/Threonine-Protein Kinase 19
}

National Cancer Institute

\section{Source}

National Cancer Institute. Serine/Threonine-Protein Kinase 19. NCI Thesaurus. Code C102911.

Serine/threonine-protein kinase 19 (368 aa, $41 \mathrm{kDa}$ ) is encoded by the human ST K19 gene. This protein plays a role in post-translational protein phosphorylation. 